\title{
The Cockcroft-Gault: A Better Predictor of Renal Function in an Overweight and Obese Diabetic Population
}

\author{
lefke Drion $^{a}$ Hanneke Joosten ${ }^{a, b}$ Liane Santing ${ }^{a}$ Susan J.J. Logtenberga,c \\ Klaas H. Groenier ${ }^{a, d}$ Aloysius G. Lieverse ${ }^{e}$ Nanne Kleefstra ${ }^{a, b, f}$ Henk J.G. Bilo ${ }^{a, b, c}$ \\ ${ }^{a}$ Diabetes Centre, Isala Clinics, Zwolle, \\ ${ }^{\mathrm{b}}$ Department of Internal Medicine, University Medical Center Groningen, Groningen, \\ ${ }^{c}$ Department of Internal Medicine, Isala Clinics, Zwolle, \\ ${ }^{\mathrm{d}}$ Department of General Practice, University Medical Center Groningen, Groningen, \\ ${ }^{\text {e }}$ Department of Internal Medicine, Maxima Medical Center Eindhoven, Eindhoven, \\ ${ }^{f}$ Langerhans Medical Research Group, the Netherlands
}

\section{Keywords}

Renal function - Creatinine clearance - Diabetes mellitus . Obesity · Estimated glomerular filtration rate

\section{Summary}

Background: The performance of the Cockcroft-Gault (CG) equation, the Modification of Diet in Renal Disease (MDRD) formula, and the Chronic Kidney Disease Epidemiology Collaboration equation (CKD-EPI) was evaluated in body mass index (BMI) categories. Material and Methods: In this retrospective cohort study in diabetic patients, creatinine clearance was measured by collecting 24-hour urines. Renal function was estimated using the CG, MDRD, and CKD-EPI. The performance of the equations was evaluated using correlation, Krippendorff's coefficient, bias, precision, and accuracy. Results: The bias of the MDRD and CKD-EPI increased from $-13.9 \mathrm{ml} / \mathrm{min} / 1.73 \mathrm{~m}^{2}$ and $-14.0 \mathrm{ml} /$ $\mathrm{min} / 1.73 \mathrm{~m}^{2}\left(\mathrm{BMl}<25 \mathrm{~kg} / \mathrm{m}^{2}\right)$, respectively, to $-31.7 \mathrm{ml} /$ $\mathrm{min} / 1.73 \mathrm{~m}^{2}$ and $-29.6 \mathrm{ml} / \mathrm{min} / 1.73 \mathrm{~m}^{2}\left(\mathrm{BMl}>30 \mathrm{~kg} / \mathrm{m}^{2}\right)$, respectively. Bias of the $C G$ decreased from $-13.4 \mathrm{ml} / \mathrm{min}$ $\left(\mathrm{BMI}<25 \mathrm{~kg} / \mathrm{m}^{2}\right)$ to $-3.2 \mathrm{ml} / \mathrm{min}\left(\mathrm{BMI}>30 \mathrm{~kg} / \mathrm{m}^{2}\right)$. With an accepted $30 \%$ dispersion, $C G$ had the largest accuracy in the overweight and obese group (76.9 and $76.8 \%$, respectively). The MDRD and CKD-EPI had an accuracy of 45.8 and $34.0 \%$ (overweight group), respectively, and 51.9 and $37.3 \%$ (obese group), respectively. Conclusions: All renal function prediction equations are biased when used in overweight or obese diabetic populations with preserved renal function. The CG provides the best estimate of kid- ney function. The limitations of renal function prediction equations should be kept in mind when making clinical decisions.

\section{Introduction}

Because of the worldwide increasing prevalence of obesity and its associated problems such as diabetes mellitus (DM) and hypertension [1-3], the number of patients with complications such as renal function loss will also increase. Diagnosing renal dysfunction at an early stage is advocated, since early changes in lifestyle and pharmacological interventions can prevent or slow down further progression of renal damage [4-6]. To facilitate early recognition of chronic kidney disease (CKD), the Kidney Disease Outcome Quality Initiative (KDOQI) guidelines were introduced [7]. These guidelines classify CKD based on structural abnormalities, persisting albuminuria and/or hematuria of glomerular origin and an estimated glomerular filtration rate (eGFR) [8, 9]. Increased urinary excretion of albumin is an early and sensitive marker of CKD due to DM and hypertension. Numerous studies have shown a strong independent association between the level of urinary protein excretion and the risk of cardiovascular mortality in populations with DM $[8,10,11]$. Besides albuminuria, eGFR remains the cornerstone for assessment and staging of CKD. Since the use of serum creatinine alone as a measure for renal function is too inaccurate, and inulin, radioactive

\section{KARGER}

Fax +497614520714

Information@Karger.de

www.karger.com (c) 2011 S. Karger GmbH, Freiburg

$1662-4025 / 11 / 0045-0393 \$ 38.00 / 0$

Accessible online at:

www.karger.com/ofa
Iefke Drion, MD

Diabetes Centre, Isala Clinics

P.O. Box 10400, 8000 GK Zwolle, the Netherlands

Tel. +3138 4247-942, Fax -694

i.drion@isala.nl 
Table 1. Prediction equations

\author{
Creatinine clearance: \\ $\mathrm{U}$ (creatinine concentration in urine; $\mu \mathrm{mol} / \mathrm{ml}) \times \mathrm{V}$ (urine volume; $\mathrm{ml} / \mathrm{min}) / \mathrm{P}($ creatinine concentration in $\mathrm{plasma} \mathrm{in}(\mu \mathrm{mol} / \mathrm{ml})$ \\ Cockroft-Gault equation $(\mathrm{ml} / \mathrm{min})$ : \\ $1.23 \times(140-$ age $) /$ serum creatinine $) \times$ weight $(\times 0.85$ for women $)$ \\ 4-variable Modification of Diet in Renal Disease (MDRD) equation ( $\left.\mathrm{ml} / \mathrm{min} / 1.73 \mathrm{~m}^{2}\right)$ : \\ $175 \times(\text { serum creatinine }(\mu \mathrm{mol} / 1) / 88.4)^{-1.154} \times$ age $(\text { years })^{-0.203}(\times 0.742$ for women $)$ \\ Chronic Kidney Disease Epidemiology Collaboration (CKD-EPI) equation ( $\left.\mathrm{ml} / \mathrm{min} / 1.73 \mathrm{~m}^{2}\right)$ : \\ $141 \times \min (\text { serum creatinine }(\mathrm{mg} / \mathrm{dl}) / \mathrm{k}, 1)^{\mathrm{a}} \times \max (\text { serum creatinine }(\mathrm{mg} / \mathrm{dl}) / \mathrm{k}, 1)^{-1.209} \times 0.993^{\text {age }}(\times 1.018$ for women $)$ \\ $\mathrm{k}=0.7$ for females and 0.9 for males; $\mathrm{a}=-0.329$ for females and -0.411 for males; $\min =\operatorname{minimum}$ of SCr $/ \mathrm{k}$ or 1 \\ $\max =$ maximum of $\mathrm{SCr} / \mathrm{k}$ or 1 .
}

tracer elements, or 24-hour urine collections are either expensive or cumbersome in daily practice, different formulae have been developed in the past decades to estimate the GFR or creatinine clearance $(\mathrm{Crcl})$.

There is considerable debate regarding the indiscriminate use and interchangeable results of the 4-variable Modification of Diet in Renal Disease (MDRD) equation [12], the Chronic Kidney Disease Epidemiology Collaboration (CKD-EPI) equation [13], and the Cockcroft-Gault (CG) equation [14] in overweight and obese patients [15-20]. The MDRD, based on GFR measurements using ${ }^{125}$ I-iothalamate, was developed in a relatively young population (subjects $<70$ years of age) with known renal disease (mean GFR $39.8 \mathrm{ml} / \mathrm{min} / 1.73 \mathrm{~m}^{2}$ ) and overt proteinuria ( $>1 \mathrm{~g}$ /day urinary protein loss). The body weight of these subjects was $\geq 80 \%$ and $\leq 160 \%$ of their standard body weight. The MDRD is considered to be reliable in subjects with a GFR $\leq 60 \mathrm{ml} / \mathrm{min} / 1.73 \mathrm{~m}^{2}$, and is indexed for a body surface area (BSA) of $1.73 \mathrm{~m}^{2}$ (which approximates the BSA of a non-overweight average-sized person) [12]. The CKD-EPI was developed in an attempt to get a better estimate of GFR in values exceeding $60 \mathrm{ml} / \mathrm{min} / 1.73 \mathrm{~m}^{2}$. It was developed in a population with a mean GFR of $68 \mathrm{ml} / \mathrm{min} / 1.73$ $\mathrm{m}^{2}$ (indexed for BSA) and a mean BMI of $28 \mathrm{~kg} / \mathrm{m}^{2}$ [13]. The $\mathrm{CG}$ is an equation to estimate the $\mathrm{Crcl}$ that was developed in a cohort of largely non-obese male subjects with a wide age range, a weight within the $10 \%$ range of fat-free body mass, and normal renal function [14]. Therefore, a CG estimate is considered to be especially reliable in Crcl levels $>60 \mathrm{ml} / \mathrm{min}$. Unlike the MDRD and the CKD-EPI, body weight is included as a variable because it is a crude estimate of muscle mass and therefore also of creatinine 'production'. Since excess body weight in an overweight and obese population usually comprises adipose tissue and not muscle mass, this formula is thought to have considerable limitations in this patient category.

Theoretically, the CG will virtually always provide higher results than the MDRD, since the CG equation not only represents glomerular function but also tubular function. Furthermore, most adults will have a larger BSA than the standard BSA of $1.73 \mathrm{~m}^{2}$ which is used in the MDRD and CKD-
EPI. This means that these differences may lead to misunderstandings and incorrect interpretation of results. Therefore, we aimed to investigate the influence of (over)weight on the performance of the MDRD and CKD-EPI equations versus the $\mathrm{CG}$ equation in diabetic patients, and to analyze the effect on the (mis)classification of CKD.

\section{Material and Methods}

\section{Study Population}

The data for this retrospective, observational, cross-sectional study were collected from May 2005 until December 2006 at the outpatient clinic of the Maxima Medical Center in Eindhoven, the Netherlands. During that period, 1,095 24-hour Crcl of adult patients with DM were collected. An anonymous database was created with data abstracted from the 'Chipsoft Electronisch Zorg Informatie Systeem' (CS-EZIS), the computerized medical record system of the Maxima Medical Center. The database thus contained data regarding 24-hour urinary creatinine, serum creatinine, $\mathrm{HbA1c}$, weight, length, age, and sex of each of these patients. In addition, BMI and BSA $\left(\right.$ BSA $\left(\mathrm{m}^{2}\right)=0.20247 \times$ height $(\mathrm{m})^{0.725} \times$ weight $\left.(\mathrm{kg})^{0.425}\right)$ [15] were calculated and added to the database. The patients were divided into 3 groups based on their BMI according to the WHO classification: a normal group (BMI 18-24.9 kg/m²), an overweight group (BMI 25-29.9 $\left.\mathrm{kg} / \mathrm{m}^{2}\right)$, and an obese group $\left(\left(\mathrm{BMI} \geq 30 \mathrm{~kg} / \mathrm{m}^{2}\right)\right.$ (www.who.int/mediacentre/ factsheets/fs311/en/index.html; accessed May 25, 2011). 13 patients with a $\mathrm{Crcl}$ of more than $250 \mathrm{ml} / \mathrm{min}$ and 2 patients who were younger than 18 years old were excluded, as the eGFR prediction equations are not validated in this patient group. In cases in which more than 1 24-hour urine sample was performed $(\mathrm{n}=236)$ in the indicated period, the most recent sample was used. Ultimately, the database contained complete data for 844 patients. The population is a mixture of type 1 diabetes mellitus (T1DM) and type 2 diabetes mellitus (T2DM) patients. The exact numbers of each type are unknown. Permission from the Medical Ethics Committee was not required, as our data only included anonymized patient characteristics and laboratory data.

\section{Renal Function Measurement}

The enzymatic Roche Modular P method, validated by isotope dilution mass spectrometry (IDMS), was used to measure serum and urinary creatinine. The 4-variable MDRD and the CKD-EPI were used to estimate GFR (for formulae, see table 1). Crcl was estimated by using the CG equation. In this study, measured $\mathrm{Crcl}$ was used as a reference value for renal function. This value was based on a 24-hour urine collection, and calculated using the formula $\mathrm{U} \times \mathrm{V} / \mathrm{P}$ (table 1 ) to calculate the 24-hour creatinine clearance rate. In order to make a better comparison between 
Table 2. Patient characteristics

\begin{tabular}{|c|c|c|c|}
\hline & $\begin{array}{l}\text { Normal } \\
\text { BMI < } 25 \mathrm{~kg} / \mathrm{m}^{2}\end{array}$ & $\begin{array}{l}\text { Overweight } \\
\text { BMI } 25-29.9 \mathrm{~kg} / \mathrm{m}^{2}\end{array}$ & $\begin{array}{l}\text { Obese } \\
\text { BMI } \geq 30 \mathrm{~kg} / \mathrm{m}^{2}\end{array}$ \\
\hline Patients, n (\%) & $243(29.0)$ & $295(35.0)$ & $306(36)$ \\
\hline Age, medium, years (IQR) & $65(48-73)$ & $63(54-71)$ & $63(56-72)$ \\
\hline Male sex, \% & 57 & 65 & 44 \\
\hline Weight, kg (IQR) & $70(63-76)$ & $80(74-90)$ & $97(89-109)$ \\
\hline BMI, kg/m² (IQR) & $23(22-24)$ & $27(26-29)$ & $33(31-37)$ \\
\hline HbA1c, \% (IQR) & $6.7(6.0-7.4)$ & $6.6(5.9-7.4)$ & $6.9(6.1-7.6)$ \\
\hline Serum creatinine, $\mu \mathrm{mol} / \mathrm{l}$ (IQR) & $78(66-93)$ & $83(71-103)$ & $78(66-98)$ \\
\hline BSA, mean, $\mathrm{m}^{2}(\mathrm{SD})$ & $1.8(0.2)$ & $1.9(0.2)$ & $2.1(0.2)$ \\
\hline Creatinine clearance, mean, $\mathrm{ml} / \mathrm{min}(\mathrm{SD})$ & $104(41)$ & $109(42)$ & $121(51)$ \\
\hline $\mathrm{CG}$, mean, $\mathrm{ml} / \mathrm{min}(\mathrm{SD})$ & $85(34)$ & $91(34)$ & $116(49)$ \\
\hline CKD-EPI, mean, $\mathrm{ml} / \mathrm{min} / 1.73 \mathrm{~m}^{2}(\mathrm{SD})$ & $82(24)$ & $77(24)$ & $77(23)$ \\
\hline CKD-EPI-BSA, mean, ml/min (SD) & $87(28)$ & $87(29)$ & $94(31)$ \\
\hline MDRD, mean, $\mathrm{ml} / \mathrm{min} / 1.73 \mathrm{~m}^{2}(\mathrm{SD})$ & $82(28)$ & $77(29)$ & $79(30)$ \\
\hline MDRD-BSA, mean, ml/min (SD) & $85(29)$ & $84(29)$ & $92(34)$ \\
\hline
\end{tabular}

$\mathrm{BMI}=$ Body mass index $\mathrm{IQR}=$ interquartile range; $\mathrm{BSA}=$ body surface area $\mathrm{CG}=$ Cockcroft-Gault equation; CKD-EPI = chronic kidney disease epidemiology collaboration equation; CKD-EPI-BSA = CKD-EPI corrected for body surface area; MDRD = Modification of Diet in Renal Disease (4-variable MDRD used in this study); MDRD-BSA = MDRD corrected for body surface area.

Table 3. Correlation and Krippendorff's coefficient (KC) for CG and eGFR values per BMI category

\begin{tabular}{|c|c|c|c|c|c|}
\hline & $\mathrm{CG}, \mathrm{ml} / \mathrm{min}(\mathrm{KC})$ & $\begin{array}{l}\text { MDRD, } \\
\mathrm{ml} / \mathrm{min} / 1.73 \mathrm{~m}^{2}(\mathrm{KC})\end{array}$ & $\begin{array}{l}\text { MDRD-BSA, } \\
\mathrm{ml} / \min (\mathrm{KC})\end{array}$ & $\begin{array}{l}\text { CKD-EPI, } \\
\mathrm{ml} / \mathrm{min} / 1.73 \mathrm{~m}^{2}(\mathrm{KC})\end{array}$ & $\begin{array}{l}\text { CKD-EPI-BSA, } \\
\mathrm{ml} / \mathrm{min}(\mathrm{KC})\end{array}$ \\
\hline $\mathrm{BMI}<25 \mathrm{~kg} / \mathrm{m}^{2}$ & $0.82^{\mathrm{a}}(0.71)$ & $0.75^{\mathrm{a}}(0.58)$ & $0.80^{\mathrm{a}}(0.66)$ & $0.76^{\mathrm{a}}(0.55)$ & $0.82^{\mathrm{a}}(0.68)$ \\
\hline BMI $25-29.9 \mathrm{~kg} / \mathrm{m}^{2}$ & $0.81^{\mathrm{a}}(0.71)$ & $0.78^{\mathrm{a}}(0.52)$ & $0.82^{\mathrm{a}}(0.62)$ & $0.79^{\mathrm{a}}(0.47)$ & $0.82^{\mathrm{a}}(0.65)$ \\
\hline $\mathrm{BMI} \geq 30 \mathrm{~kg} / \mathrm{m}^{2}$ & $0.75^{\mathrm{a}}(0.75)$ & $0.72^{\mathrm{a}}(0.42)$ & $0.77^{\mathrm{a}}(0.58)$ & $0.72^{\mathrm{a}}(0.33)$ & $0.78^{\mathrm{a}}(0.57)$ \\
\hline
\end{tabular}

${ }^{\text {a}}$ Spearman's correlation coefficient.

$\mathrm{KC}=$ Krippendorff's coefficient; BMI = body mass index; BSA = body surface area; $\mathrm{CG}=$ Cockcroft-Gault equation;

eGFR = estimated glomerular filtration rate; CKD-EPI = chronic kidney disease epidemiology collaboration equation;

CKD-EPI-BSA = CKD-EPI corrected for body surface area; MDRD = Modification of Diet in Renal Disease (4-variable MDRD used in this study); MDRD-BSA = MDRD corrected for body surface area.

the estimations of the MDRD/CKD-EPI on the one hand versus the CG/ $\mathrm{Crcl}$ on the other hand, the results of the MDRD and CKD-EPI were recalculated for the individual BSA (using the DuBois formula [15] as mentioned above) of each patient (designated as MDRD-BSA and CKD-EPI-BSA, respectively).

\section{Statistical Analysis}

Data analysis was performed using SPSS version 16.0 (SPPS Inc., Chicago, IL, USA). Demographic data were stratified according to BMI categories, and presented as median (interquartile range, IQR) or mean (standard deviation, SD), depending on whether data were skewed or not. The Student's t-test, the chi-square test, or ANOVA were used to compare demographic characteristics and the values of the renal function prediction equations between the BMI categories. The accuracy of the renal function prediction formulae for the different BMI categories was compared using the McNemar test. The performance of the GFR prediction equations, the GFR prediction equations corrected for BSA, and the CG were compared by calculating correlation, Krippendorf's coefficient [16], bias, precision (the SD of the bias), and accuracy for each BMI category. Spearman's coefficient of correlation was calculated for each BMI category to determine the correlation between $\mathrm{Crcl}$ and the results of the
MDRD, the MDRD-BSA, the CKD-EPI, the CKD-EPI-BSA, and the CG. Krippendorff's coefficient was used as an aggregate measure for method concordance. A Krippendorff's coefficient of 1 shows perfect concordance between 2 methods and a Krippendorff's coefficient of -1 shows perfect discordance [16]. Bias was defined as the mean difference between the renal function prediction equations and $\mathrm{Crcl}$, whereas precision was defined as the SD of this difference. Accuracy (a combination of bias and precision), and the percentage of patients who had an estimated kidney function within $30 \%$ and $50 \%$ limits of the $\mathrm{Crcl}$, were calculated.

\section{Results}

\section{Population Characteristics and Design}

The patient characteristics of this study are presented in table 2. The mean (SD) Crcl of the overall study population was 112 (45) $\mathrm{ml} / \mathrm{min}$. The mean renal function of the overall population estimated with the MDRD, MDRD-BSA, CKDEPI, CKD-EPI-BSA, and CG was $76(25) \mathrm{ml} / \mathrm{min} / 1.73 \mathrm{~m}^{2}, 87$ 
Fig. 1. Mean bias per BMI category. Mean bias $\left(\mathrm{ml} / \mathrm{min} / 1.73 \mathrm{~m}^{2}\right)$ of each renal function prediction equation stratified according to BMI category $\left(\mathrm{kg} / \mathrm{m}^{2}\right)$. Bias is defined as mean difference between estimate and creatinine clearance. MDRD-B = MDRD corrected for body surface area.

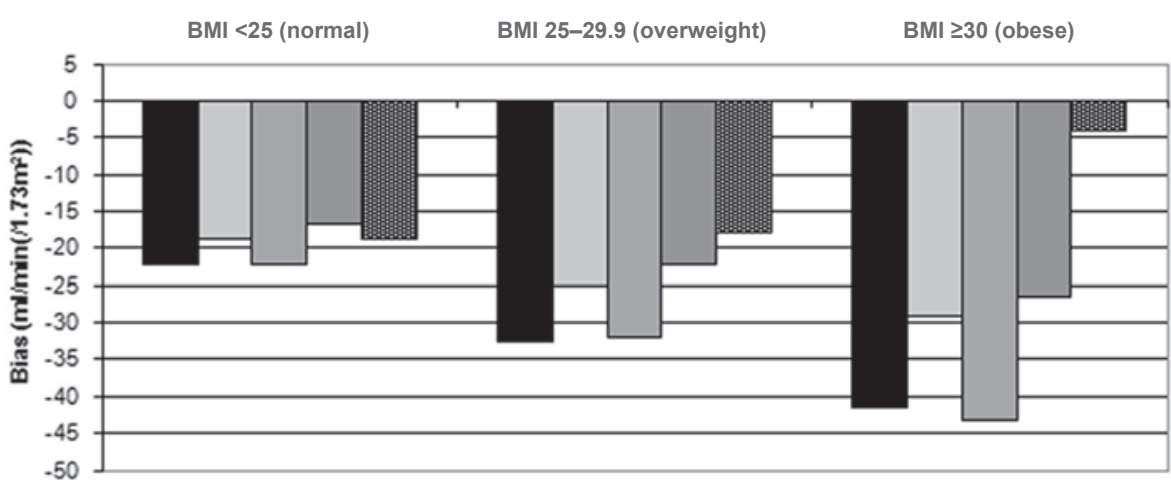

-MDRD $\left(\mathrm{m} / \mathrm{min} / 1.73 \mathrm{~m}^{2}\right) \quad$ aMDRD-B $(\mathrm{m} / \mathrm{min}) \quad$ aCKD-EPI $\left(\mathrm{m} / \mathrm{min} / 1.73 \mathrm{~m}^{2}\right)$ aCKD-EPI-B $(\mathrm{m} / \mathrm{min})$ aC $(\mathrm{m} / \mathrm{min})$

Table 4. Precision and accuracy for eGFR prediction equations and CG per BMI category

\begin{tabular}{|c|c|c|c|c|c|c|}
\hline & & $\mathrm{CG}, \mathrm{ml} / \mathrm{min}$ & $\begin{array}{l}\text { MDRD, } \\
\mathrm{ml} / \mathrm{min} / 1.73 \mathrm{~m}^{2}\end{array}$ & $\begin{array}{l}\text { MDRD-BSA, } \\
\mathrm{ml} / \mathrm{min}\end{array}$ & $\begin{array}{l}\text { CKD-EPI, } \\
\mathrm{ml} / \mathrm{min} / 1.73 \mathrm{~m}^{2}\end{array}$ & $\begin{array}{l}\text { CKD-EPI-BSA, } \\
\mathrm{ml} / \mathrm{min}\end{array}$ \\
\hline \multirow{3}{*}{$\begin{array}{l}\mathrm{BMI}<25 \mathrm{~kg} / \mathrm{m}^{2} \\
\quad(\text { normal weight })\end{array}$} & precision $^{\mathrm{a}}$ & 25.5 & 28.3 & 25.9 & 28.0 & 24.9 \\
\hline & accuracy $^{\mathrm{b}} 30 \%$ & 70.4 & 63.3 & 72.0 & 67.1 & 67.1 \\
\hline & accuracy $50 \%$ & 95.1 & 94.7 & 96.3 & 95.1 & 95.1 \\
\hline \multirow{3}{*}{$\begin{array}{l}\text { BMI } 25-29.9 \mathrm{~kg} / \mathrm{m}^{2} \\
\quad \text { (overweight) }\end{array}$} & precision & 24.9 & 28.4 & 25.2 & 26.9 & 24.3 \\
\hline & accuracy $30 \%$ & 76.9 & 45.8 & 67.5 & 51.9 & 51.9 \\
\hline & accuracy $50 \%$ & 96.9 & 92.5 & 97.3 & 94.2 & 94.2 \\
\hline \multirow{3}{*}{$\begin{array}{l}\mathrm{BMI} \geq 30 \mathrm{~kg} / \mathrm{m}^{2} \\
\quad(\text { obese })\end{array}$} & precision & 38.0 & 36.2 & 34.8 & 37.7 & 33.0 \\
\hline & accuracy $30 \%$ & 76.8 & 34.0 & 58.5 & 37.3 & 37.3 \\
\hline & accuracy $50 \%$ & 90.5 & 82.0 & 94.4 & 85.3 & 85.3 \\
\hline
\end{tabular}

${ }^{\mathrm{a}}$ Defined as $1 \mathrm{SD}$ of the bias $\left(\mathrm{ml} / \mathrm{min} / 1.73 \mathrm{~m}^{2}\right)$.

${ }^{b}$ Defined as percentage of GFR estimation within \pm 30 and $\pm 50 \%$ range of respective creatinine clearance measurements.

$\mathrm{BMI}=$ Body mass index; $\mathrm{BSA}$ = body surface area $\mathrm{CG}=$ Cockcroft-Gault equation; $\mathrm{eGFR}=$ estimated glomerular filtration rate;

CKD-EPI = chronic kidney disease epidemiology collaboration equation; CKD-EPI-BSA = CKD-EPI corrected for body surface area;

MDRD = Modification of Diet in Renal Disease (4-variable MDRD used in this study); MDRD-BSA = MDRD corrected for body surface area.

(31) $\mathrm{ml} / \mathrm{min}, 78(24) \mathrm{ml} / \mathrm{min} / 1.73 \mathrm{~m}^{2}, 90(30) \mathrm{ml} / \mathrm{min}$, and 99 (42) $\mathrm{ml} / \mathrm{min}$, respectively. The total study population was equally divided between the BMI categories, and included subjects across a wide range of ages (20-92 years), with BMI scores ranging between 15 and $58 \mathrm{~kg} / \mathrm{m}^{2}$. The Crcl values ranged between 11 and $250 \mathrm{ml} / \mathrm{min}$. Although nonsignificant, there were considerable differences in sex distribution between the BMI categories. No significant differences in age and $\mathrm{HbA} 1 \mathrm{c}$ were observed between the BMI categories. After calculating the results of the GFR prediction equations and the CG equation for each BMI category, only the MDRD result was significantly different between the normal group $\left(\mathrm{BMI}<25 \mathrm{~kg} / \mathrm{m}^{2}\right)$ and the overweight group (BMI $25-29.9 \mathrm{~kg} / \mathrm{m}^{2}$ ) $(\mathrm{p}<0.04)$. Between the normal and obese group, significant differences were found for the Crcl value $(\mathrm{p}<0.01)$, MDRDBSA $(\mathrm{p}<0.01)$, and CG result $(\mathrm{p}<0.001)$. However, when the GFR prediction equations were not corrected for BSA, no significant differences were found (MDRD equation: $\mathrm{p}<0.95$, CKD-EPI equation: $\mathrm{p}<0.97)$.

\section{Correlation and Krippendorff's Coefficient}

Both GFR estimates, also after a correction for BSA, and the CG result were correlated with the Crcl value of each BMI category (table 3). Overall, the Spearman's correlation coefficient was 0.73 for the MDRD, 0.80 for the MDRD-BSA, 0.74 for the CKD-EPI, 0.81 for the CKD-EPI-BSA, and 0.78 for the CG equation. If no correction for BSA takes place, the correlation between the $\mathrm{CG}$ and the $\mathrm{Crcl}$ proves to be superior to the GFR prediction equations in all BMI categories, except for the MDRD equation in the normal weight category (as might be expected). When GFR formulae are corrected for BSA, the correlation between the CKD-EPI-BSA and MDRD-BSA results is stronger than between the $\mathrm{CG}$ result and $\mathrm{Crcl}$ in all BMI categories. Because correlation alone is insufficient to prove the concordance among methods, the Krippendorff's coefficient was calculated (table 3). The best concordance was found between the CG result and Crcl within all BMI categories. The CKD-EPI result had the worst concordance with $\mathrm{Crcl}$ in all BMI categories, even after correction for BSA. 


\section{Bias and Precision}

All prediction equations had a negative bias in the various BMI categories. The bias varied widely, as can be seen in figure 1. The higher the BMI, the greater the mean bias for both the MDRD and the CKD-EPI equation (fig. 1). When the MDRD and the CKD-EPI were corrected for BSA, the results were similar. However, the mean bias for these 2 equations did not increase as much in the higher BMI categories (fig. 1). For the $\mathrm{CG}$ equation, a decreasing trend in bias was observed with increasing $\mathrm{BMI}$, from $-18.7 \mathrm{ml} / \mathrm{min}$ in BMI $<25 \mathrm{~kg} / \mathrm{m}^{2}$ to $-4.0 \mathrm{ml} / \mathrm{min}$ in $\mathrm{BMI} \geq 30 \mathrm{~kg} / \mathrm{m}^{2}$ ( $\left.\mathrm{p}<0.001\right)$. No significant differences in performance were found between the CKD-EPI and the MDRD equations in the normal weight and overweight group ( $p=0.88$ and $p=0.50$, respectively). In the obese patient group, the MDRD performed significantly better than the CKD-EPI $(\mathrm{p}=0.01)$. The precision of all these formulas varied widely in all BMI categories (table 4).

\section{Accuracy}

In table 4, the accuracy of the various renal function estimates is presented for each BMI category. The CG had the best accuracy $(>70.4 \%)$ in all BMI categories. The CKD-EPI equation had a better accuracy than the MDRD equation in all BMI categories (when a dispersion of $30 \%$ was tolerated), although the difference in accuracy was only significant in the overweight group $(<0.01)$; accuracy decreased with increasing BMI. However, when the GFR prediction equations were corrected for BSA, the MDRD-BSA performed significantly better in all BMI categories than the CKD-EPI-BSA $(\mathrm{p}<0.01)$, and the higher the BMI, the lower the accuracy.

\section{Discussion}

This study shows that the CG is a better predictor of renal function than the MDRD and the CKD-EPI in diabetic patients, especially when patients are overweight or obese, at least when $\mathrm{Crcl}$ is used as a reference value. The MDRD and CKD-EPI equations provided less accurate results for overweight and obese patients. Even though the renal function in the studied population was good (mean $\mathrm{Crcl} 112 \mathrm{ml} / \mathrm{min}$ ), the recently developed CKD-EPI did not perform significantly better than the MDRD. When the MDRD and CKD-EPI were corrected for BSA, bias and accuracy improved. Even so, the CG outperformed the GFR prediction equations in the overweight and obese patient group.

The limitations of creatinine-based prediction equations in overweight and obese populations have been discussed in the literature before [17-22]. There is still an ongoing debate about renal function prediction equations in these populations. A condition frequently encountered in obese and diabetic patients that should be taken into account in this debate is renal hyperfiltration. The suggested underlying mechanism is that progressive obesity alters renal hemodynamics, leading to an increase in GFR of each single nephron since the number of nephrons will not increase with increasing body fat [23]. Ultimately, nephrons will function near to or on maximum capacity, i.e. hyperfiltration. Correcting GFR for BSA obscures this problem, as was shown in a cohort of 81 obese patients (BMI $41 \pm 9 \mathrm{~kg} / \mathrm{m}^{2}$ ) with a mean GFR of $101 \pm$ $24 \mathrm{ml} / \mathrm{min}$ (measured by ${ }^{51} \mathrm{Cr}$-EDTA) and a mean indexed GFR of $76 \pm 16 \mathrm{ml} / \mathrm{min} / 1.73 \mathrm{~m}^{2}$ [24]. When the absolute GFR or the indexed GFR were used as a reference, the MDRD formula underestimated (mean difference $-11 \pm 20 \mathrm{ml} / \mathrm{min}$ ) and overestimated (mean difference $14 \pm 18 \mathrm{ml} / \mathrm{min} / 1.73 \mathrm{~m}^{2}$ ) the measured GFR, respectively. The observed underestimation of the GFR using the MDRD can be expected based on previous literature; however, the overestimation when using an indexed GFR is remarkable and suggests that back-correction for BSA is needed [24].

Although overweight and obesity have almost reached epidemic proportions nowadays, the Caring for Australians with Renal Impairment (CARI) guidelines are the only guidelines that mention the influence of weight on the GFR prediction equations [25]. These guidelines are also the only ones warning against the unreliable prediction results of the MDRD equation in an overweight and obese population [25]. The influence of weight on renal function equations should however, be considered, especially since many laboratories have started to use automated reporting of MDRD estimates. More importantly, clinical decisions are based on these renal function estimates.

The observation in our study, that the CG equation had the least bias in overweight and obese subjects, is supported by previous publications $[17,18]$. In a population of newly diagnosed T2DM patients with a mean isotopic GFR of $115 \mathrm{ml} /$ $\min / 1.73 \mathrm{~m}^{2}$, the $\mathrm{CG}$ equation had the most pronounced bias in lean subjects (mean $-20.6 \mathrm{ml} / \mathrm{min} / 1.73 \mathrm{~m}^{2}$, confidence interval $(\mathrm{CI})-23.9$ to -17.3$)$, and a bias that diminished with increasing body weight $\left(-5.6 \mathrm{ml} / \mathrm{min} / 1.73 \mathrm{~m}^{2}\right.$ in an obese population). Contrarily, the bias of the MDRD increased (from $-21.3 \mathrm{ml} / \mathrm{min} / 1.73 \mathrm{~m}^{2}$ in the normal weight group to $-28.9 \mathrm{ml} /$ $\min / 1.73 \mathrm{~m}^{2}$ in the obese group), while accuracy decreased [19]. The fact that we found more pronounced results compared to the study by Chudleigh et al. [19] might be due to the use of $\mathrm{Crcl}$ values instead of ${ }^{51} \mathrm{Cr}$-EDTA values as a reference for renal function. Verhave et al. [17] studied the performance of the CG and MDRD equations in a diverse cohort of outpatients with serum creatinine levels of less than $1.5 \mathrm{mg} / \mathrm{dl}$ $(<133 \mu \mathrm{mol} / \mathrm{l})$. In their study, a rather similar trend for the CG was found, except that in the obese population an overestimation of $+10.1 \mathrm{ml} / \mathrm{min}$ was found. This is in contrast to our study in which we found a small underestimation. Also in contrast to our findings, the investigators found that the MDRD equation underestimated the GFR to a certain extent (approximately $-12.4 \mathrm{ml} / \mathrm{min} / 1.73 \mathrm{~m}^{2}$ ), irrespective of BMI [17]. It is possible that their results slightly differ from our results because of differences in creatinine measurement. In our study, creatinine was calibrated to IDMS. 
The influence of weight on the CKD-EPI has not yet been evaluated in a cohort of diabetic subjects. In a recently published study performed among potential kidney donors (mean Crcl $78.2 \mathrm{ml} / \mathrm{min} / 1.73 \mathrm{~m}^{2}$ ), the researchers found that the CKD-EPI and the MDRD equations were not influenced by BMI, contrary to the CG [20].

Many of the above mentioned studies, comparing the performance of the CG and the MDRD, use an indexed CG equation (often the standard BSA of $1.73 \mathrm{~m}^{2}$ ). In our opinion, this is incorrect. Since weight is one of the clinical variables included in the CG equation, a correction for BSA will result in a double correction for weight. This double correction may well have influenced the performance of the equation in these studies. Moreover, a correction to a standard BSA of $1.73 \mathrm{~m}^{2}$ may result in a worse performance of the MDRD and CKD-EPI equations. In patients with a normal BMI, the impact of a correction to a standard BSA of $1.73 \mathrm{~m}^{2}$ is rather small, since $1.73 \mathrm{~m}^{2}$ is approximately the BSA of a non-overweight person. However, such a correction will lead to considerable underestimation of renal function in obese patients, since a lot of obese people have a BSA which grossly exceeds $1.73 \mathrm{~m}^{2}$. When we corrected the values in our study to a standard BSA of $1.73 \mathrm{~m}^{2}$, the MDRD and CKD-EPI equations did indeed perform worse. But when we corrected the data to the actual BSA of participants, the performance of both the MDRD equation and the CKD-EPI equation improved considerably. Another reason why the MDRD equation in our study performed worse than the other equations might be that the average renal function in the study population was good and the MDRD equation has only been validated in a population with impaired renal function (MDRD $<60 \mathrm{ml} / \mathrm{min} / 1.73 \mathrm{~m}^{2}$ ).

Finally, $\mathrm{Crcl}$ is not a true reflection of GFR. Still, $\mathrm{Crcl}$ is a common way to measure renal function in daily practice; contrarily to various isotopic clearance techniques or other clear- ance methods that are reserved for research purposes. Unfortunately, details concerning duration of DM, blood glucose lowering treatment, and the presence of albuminuria are not available for this population due to the method of data collection. The inclusion of such data would have allowed the analysis to be more complete.

An important strength of our study is that creatinine clearances in our cohort ranged from 10.7 to $249.5 \mathrm{ml} / \mathrm{min}$. In addition, the majority of our subjects had normal or mildly decreased renal function. The performances of the CG, MDRD, and CKD-EPI equations could therefore be assessed over a wide range of renal functions. Furthermore, recent studies have emphasized the importance of careful calibration of serum creatinine measurements in order to further improve the reliability of the GFR estimation formulae [26]. In this study, IDMS-calibrated serum creatinine measurements were used, so misclassification of renal function due to less reliable creatinine testing is unlikely.

\section{Conclusion}

In this study, performed among diabetic patients in various weight categories, the $\mathrm{CG}$ was the best predictor of renal function compared to the 4-variable MDRD and CKD-EPI when used in an overweight or obese population. The recently developed CKD-EPI equation has no additional value over the existing prediction equations. When the existing prediction equations are used in clinical practice, their disadvantages should be kept in mind when making decisions based on the results of these equations.

\section{Disclosure Statement}

No potential conflicts of interest, including specific financial interests and relationships and affiliations relevant to the subject matter discussed in this manuscript, can be mentioned.

\section{References}

1 Berghofer A, Pischon T, Reinhold T, Apovian CM Sharma AM, Willich SN: Obesity prevalence from a European perspective: a systematic review. BMC Public Health 2008;8:200.

2 Must A, Spadano J, Coakley EH, Field AE, Colditz G, Dietz WH: The disease burden associated with overweight and obesity. JAMA 1999;282:15231529.

>3 Wilson PW, D'Agostino RB, Sullivan L, Parise H, Kannel WB: Overweight and obesity as determinants of cardiovascular risk: the Framingham experience. Arch Intern Med 2002;162:1867-1872.

4 Lewis EJ, Hunsicker LG, Clarke WR, Berl T, Pohl MA, Lewis JB, Ritz E, Atkins RC, Rohde R, Raz I; Collaborative Study Group: Renoprotective effect of the angiotensin-receptor antagonist irbesartan in patients with nephropathy due to type 2 diabetes: N Engl J Med 2001;345:851-860.
5 Jafar TH, Schmid CH, Landa M, Giatras I, Toto R, Remuzzi G, Maschio G, Brenner BM, Kamper A, Zucchelli P, Becker G, Himmelmann A, Bannister $\mathrm{K}$, Landais P, Shahinfar S, de Jong PE, de Zeeuw D, Lau J, Levey AS: Angiotensin-converting enzyme inhibitors and progression of nondiabetic renal disease: a meta-analysis of patient-level data. Ann Intern Med 2001;135:73-87.

6 Barret BJ, Parfrey PS, Morgan J, Barré P, Fine A, Goldstein MB, Handa SP, Jindal KK, Kjellstrand CM, Levin A, Mandin H, Muirhead N, Richardson RM: Prediction of early death in end-stage renal disease patients starting dialysis. Am J Kidney Dis 1997;29:214-222.

7 National Kidney Foundation: K/DOQI clinical practice guidelines for chronic kidney disease: evaluation, classification, and stratification. Am J Kidney Dis 2002;39:S1-D246.
8 De Boer I, Katz R, Cao JJ, Fried LF, Kestenbaum B, Mukamal K, Rifkin D, Sarnak MJ, Shlipak MG, Siscovick DS: Cystatin C, albuminuria, and mortality among older adults with diabetes. Diabetes Care 2009;32:1833-1838.

9 Deckert T, Feldt-Rasmussen B, Borch-Johnsen $\mathrm{K}$, Jensen T, Kofoed-Enevoldsen A: Albuminuria reflects widespread vascular damage. The Steno hypothesis. Diabetologia 1989:32:219-226.

10 Van der Velde M, Matsushita K, Coresh J, Astor BC, Woodward M, Levey AS, de Jong PE, Gansevoort RT and the Chronic Kidney Disease Prognosis Consortium: Lower estimated glomerular filtration rate and higher albuminuria are associated with all-cause and cardiovascular mortality. A collaborative meta-analysis of high-risk population cohorts. Kidney Int 2011;79:1341-1352. 
11 O'Hare A, Hailpern SM, Pavkov ME, Rios-Burrows N, Gupta I, Maynard C, Todd-Stenberg J, Rodriguez R, Hemmelgarn B, Saran R, Williams DE: Prognostic implication of the urinary albumin to creatinine ratio in veterans of different ages with diabetes. Arch Intern Med 2010;170:930-936.

12 Levey AS, Bosch JP, Lewis JB, Greene T, Rogers N, Roth D: A more accurate method to estimate glomerular filtration rate from serum creatinine: a new prediction equations. Modification of Diet in Renal Disease Study Group. Ann Intern Med 1999;130:461-470.

13 Levey AS, Stevens LA, Schmid CH, Zhang YL, Castro AF 3rd, Feldman HI, Kusek JW, Eggers P, Van Lente F, Greene T, Coresh J;CKD-EPI (Chronic Kidney Disease Epidemiology Collaboration): A new equation to estimate glomerular filtration rate. Ann Intern Med 2009;150:604-612.

14 Cockcroft DW, Gault MH: Prediction of creatinine clearance from serum creatinine. Nephron 1976;16:31-41.

15 DuBois M, DuBois E: A formula to estimate the approximate surface area if height and weight be known. Arch Intern Med 1916;17:863-871.

16 Krummenauer F, Doll G: Statistical methods for the comparison of measurements derived from orthodontic imaging. Eur J Orthod 2000;22:257-269.

17 Verhave JC, Fesler P, Ribstein J, du Cailar G, Mimran A: Estimation of renal function in subjects with normal serum creatinine levels: influence of age and body mass index. Am J Kidney Dis 2005;46:233-241.

18 Cirillo M, Anastasio P, De Santo NG: Relationship of gender, age, and body mass index to errors in predicted kidney function. Nephrol Dial Transplant 2005;20:1791-1798.

19 Chudleigh RA, Dunseath G, Peter R, Harvey JN, Ollerton RL, Luzio S, Owens DR: Influence of body weight on the performance of glomerular filtration rate estimators in subjects with type 2 diabetes. Diabetes Care 2008;31:47-49.

20 Michels WM, Grootendorst DC, Verduijn M, Elliot EG, Dekker FW, Krediet RT: Performance of the Cockcroft-Gault, MDRD and new CKD-EPI formulas in relation to GFR, age, and body size. Clin J Am Soc Nephrol 2010;5:1003-1009.

-21 Rigalleau V, Lasseur C, Perlemoine C, Barthe N, Raffaitin C, Chauveau P, Combe $\mathrm{C}$, Gin H: Cockcroft-Gault formula is biased by body weight in diabetic patients with renal impairment. Metabolism 2005;55:108-112.

22 Froissart M, Rossert J, Jacquot C, Paillard M, Houillier P: Predictive performance of the Modification of Diet in Renal Disease and Cockcroft-Gault equations for estimating renal function. J Am Soc Nephrol 2005;16:763-773.

23 Delanaye P, Mariat C, Cavalier E, Krzesinski JM: Errors induced by indexing glomerular filtration rate for body surface area: reduction ad absurdum. Nephrol Dial Transplant 2009;24:3593-3596.

24 Chagnac A, Weinstein T, Korzets A, Ramadan E, Hirsch J, Gafter U: Glomerular hemodynamics in severe obesity. Am J Physiol Renal Physiol 2000;278:F817822

25 CARI: The CARI guidelines use of estimated glomerular filtration rate to assess level of kidney function. Retrieved January 2010 from www.cari.org.au.

26 Myers GL, Miller WG, Coresh J, Fleming J, Greenberg N, Greene T, Hostetter T, Levey AS, Panteghini M, Welch M, Eckfeldt JH; National Kidney Disease Education Program: Recommendations for improving serum creatinine measurement: a report from the Laboratory Working Group of the National Disease Education Program. Clin Chem 2006;52:5-18.

Renal Function Prediction Equations and

Body Mass Index 